FACTA UNIVERSITATIS

Series: Visual Arts and Music Vol. 7, No 1, 2021, pp. 53-64

https://doi.org/10.22190/FUVAM2101053K

Original scientific paper

\title{
THE EFFECT OF MUSICAL GESTURES ON AN AUDIENCE: EXAGGERATED OR DEADPAN GESTURES
}

\author{
UDC 159.925.8:78
}

\begin{abstract}
Aleksandar Kodela
Student of Master Degree, University of Ljubljana, Faculty of Arts, Slovenia

Abstract. In the last two decades the scope of scientific papers related to the study of musical gestures increased enormously thanks to the development of data collection technology. The aim of this paper was to contribute to this topical area of psychology of music through the study of musical gestures during performance, i.e. to explain and systematise the visual experience of the audience when a performer made exaggerated or deadpan gestures during performance. This study was based on the questionnaire research method where examinees rated the performance of two performers by using a scale from 1 to 5. During his performance the first performer made exaggerated gestures, while the other made deadpan ones. The results that we obtained proved that exaggerated gestures disturbed visual experience of the listeners regardless whether they were formally educated in music or not. The results also showed considerable achievements in the domain of musical gestures and could be largely used for both pedagogical and performing purposes.
\end{abstract}

Key words: gesture, movement, expression, piano performance, perception

\section{INTRODUCTION}

Music need not be performed more than books need be read aloud, for its logic is perfectly presented on the printed page, and the performer, for all his intolerant arrogance is totally unnecessary, except as his interpretations make the music understandable to an audience, unfortunate enough not to be able to read it in print.

(Schönberg \& Newlin 1980, 164)

Received April 28, 2021 / Accepted May 11, 2021

Corresponding author: Aleksandar Kodela

University of Ljubljana, Faculty of Arts

Aškerčeva 2, 1000 Ljubljana, Slovenia

E-mail: akodela1993@gmail.com 
At the beginning of the twentieth century the way in which we experienced music changed forever. Earlier, with their active listening, perception and experience, listeners were part of the musical performance. At the beginning of the twentieth century the appearance and use of numerous devices for sound recording and reproduction consequently led to increasingly great differences between what we heard and saw in the musical sense. Today, blended visual and aural experience is no longer necessary; only aural aspect is also possible. This certainly does not imply that the auditory aspect is more important during performance. On the contrary, some research pointed to visual experience as important (by some opinions the most important) part of musical performance (Davidson 1993, 1994; Laberge 2016; Wanderley et al. 2007).

In order to perform music, the human body is not necessarily involved in physical engagement with the musical instrument and correct interpretation of a musical piece only; it is also capable of transmitting expressive and affective content of a musical piece similar to what the composer himself experienced (Kršić Sekulić 1990). In her pioneer research in musical gestures, Davidson (1994) conducted a survey where the participants, divided in three groups had the task to recognise visual intensions of performers by watching the video of musical performance. For the visual aspect she used the point light method developed by Johansson (1973), where the complete visual image of a performer was not seen, as could be expected; only the points of light that corresponded to significant parts of the body (shoulders, head, hands etc.) were visible instead. The first group of participants could see the video only; the second could hear it, while the third group could both see and hear the performance. The results of the survey show that the group who only saw the movements of performers was more successful at decoding expressive intentions in comparison to the groups that watched and/or listened the recording of the same performance. With the results of this research Davidson proved that the visual aspect was not only an important part of musical performance, but also that it better transmitted expressive intentions of performers in comparison to auditory or aural-visual aspects (Davidson 1994). By investigating movements during musical performance and their application in musical education Émile Jaques-Dalcroze emphasised that a body movement was decisive in the process of combining musical elements and focusing on musical expression (Ačić et al. 2019) ${ }^{1}$.

The research of David McNeill (1992) drew special attention to the study of gestures. McNeill modified original classification of gestures of Ekman and Friesen (1969) and presented his classification based on ideas of other authors. He classified human speech gestures as lexical (gestures which served to illustrate the action that elaborated the reoccurring speech), deictic (where the upper part of the body was used to indicate action, person or object), emblems (conventionally and culturally conditioned, used as substitutes for words), metaphoric gestures (similar to lexical, however, by contrast representing an abstract property of an object), and beat gestures (in tune with the rhythm of speech, used to emphasise something). McNeill et al. (2002) also found that gestures of speech and movement originated from a mutual semantic source. Speaking of comparison between speech and music Robert Finley indirectly compared monotonous speech with deadpan gestures and emphasised that during the performance of a musical piece such gestures created only a simple reproduction of the score, therefore without expressive nature (Todorović 2006). From the above stated research we could conclude

\footnotetext{
${ }^{1} \mathrm{He}$ used this statement as a starting point for development of Eurhythmics method.
} 
that music is a means of communication like speech, and that musical performance and public speech have a lot in common.

Bearing in mind everything stated, our attention will be further focused on the significance of musical gestures. At the early stages of research in musical gestures while watching the performance of famous Canadian pianist Glenn Gould, F. Delalande (1988) managed to classify musical gestures into the categories of effective, accompanying and figurative. By Delalande, effective gestures involve those connected with sound production on the instrument (e.g. finger pressure on the keyboard, hand movements during bowing over strings etc.) Accompanying or supporting gestures "follow" effective gestures, and are in fact movements of the body (e.g. movements of shoulders, head, and facial expressions) that occur during the performance, but, by contrast to effective gestures, are not connected with sound production. Delalande used the term figurative gestures for the third group. These are sound gestures experienced by an audience through the produced sound (e.g. a change in articulation of tones, melodic variances, etc.). In contrast to effective and accompanying, they do not correspond directly to physical gestures. As it will be seen later, the accompanying gestures are of special importance in this paper. ${ }^{2}$

Before the 1990s the visual aspect of musical performance was not widely studied in the psychology of music. However, remarkable development of technology and better approach to data collection (e.g. camera motion capture systems) led to an increased number of studies that were focused on the visual aspect of musical performance in the last twenty years (Thompson 2007).

Investigating facial expressions during vocal performance, Livingstone et al. (2011) found out that the examinees were successful at recognising certain emotions that were visible on the faces of performers during a show. ${ }^{3}$ In that way the authors proved that facial expressions of performers were a significant element during the performance of a vocal or vocal-instrumental piece.

While studying gestures and musical expressions of pianists, Laberge et al. (2016) investigated their effect during a performance. They concluded that pianists could play expressively as long as they are limited by a "quantity" of their gestures.

Why do pianists make various gestures during their performance? There are a few possible explanations for various types of movements used by pianists. First, by their gestures during a performance pianists can express a reaction to the produced sounds (or more simply - react to sounds they produce on the instrument). However, there are analogous movements of self-stimulation, which we can, for example, notice in speech as well. Performers often use movements that make them "feel comfortable in the social context of performance and/or enjoy musical sounds they create on the instrument" (Davidson \& Correia 2002, 253).

During a performance it is important how much a performer uses musical gestures. In his study Thompson found that with the increased level of expression, pianists increased the scope of their movements in shoulders, head and wrists. This indicates that more accompanying gestures imply higher musical expression.

Some research shows that during their performance, popular music performers use specific body movements which are the function of song lyrics. They often involve a

\footnotetext{
${ }^{2}$ During performance, accompanying gestures can be compared with paralinguistic gestures in speech.

${ }^{3}$ The interviewed people involved in the research were more successful at recognising emotions of happiness, and sorrow, while they were less successful at recognising neutral emotions on the faces of performers.
} 
conscious attempt of a performer to include an audience in the performance (Davidson \& Correia 2002).

Style and use of musical gestures are also dependent on the cultural context of the performer's background. Gellrich (1991) concluded that many gestures were in fact culturally rooted together with their meanings. Apart from culture, performers may take over the gestures from their teachers, peers or even from people they see on television (Davidson \& Correia 2002).

The fact that an audience that is inexperienced in listening to music completely relies on the visual aspect of performance speaks in favour of gestures. However, in her paper, Davidson (2002) points out that exaggerated gestures are not welcome during performance. She emphasizes that "too many movements might create an overly exaggerated performance and too few movements might make the performance appear stilted. One may recall, for example, that although grand flourishing gestures were fashionable in nineteenth-century musical performance, Liszt was referred to by Glinka as an "exaggerator of nuance" (Davidson \& Correia 2002, 258).

The primary aim of this study is to indicate whether enormously expressive communication with specific gestures in the performance of a musical piece may produce better or worse effects on the audience. Numerous aspects of body movements of performers are identified previously in this text. We think that pronounced gesticulation does not leave an audience with good impression, since it predominantly diverts a listener's attention from sound to the visual aspect of musical performance. We will discuss the following questions further:

1. How does an audience rate exaggerated and deadpan gestures of a performer?

2. Does an audience think that gestures have significant effect on complete experience of a musical piece?

3. Can exaggerated gestures establish better or poorer communication with the audience?

In order to obtain reliable answers to these questions we conducted a survey where the participants had the task to estimate the performance of pianists with exaggerated and deadpan gestures based on two videos.

\section{METHODOLOGICAL FRAMEWORK FOR RESEARCH}

The organisation of research was based on quantitative approach, where data were obtained through a questionnaire with closed-ended survey questions. The questionnaire consisted of 10 questions, and the estimated answering time was 3-4 minutes. The examinees were first shown two video interpretations of the same piece (Claude Debussy - Clair de Lune). The first performer was Fazil Say, who played the piece with exaggerated gestures, while the second performer Victor Borge interpreted the same piece with deadpan gestures.

Then the survey questionnaire was tested to estimate whether the examinees found the questions and the offered answers clear enough. The comments helped with improving the contents and the methodology of the questionnaire. The questionnaire was in three languages (Slovenian, Serbian and English). It was posted on the Internet platform Google Forms and then on social network Facebook (students' groups, organisations, etc.). Also, the questionnaire was sent to people who were estimated as fitted for the research through Viber and Whatsapp applications. The data were obtained from 27 May - 8 June 2020. 
The total of 964 examinees participated in the research, out of whom $386(40 \%)$ had no formal musical education (Figure 1), 237 (24.6\%) completed primary, 125 (13\%) completed secondary music school, while 216 (22.4\%) examinees completed higher musical education.

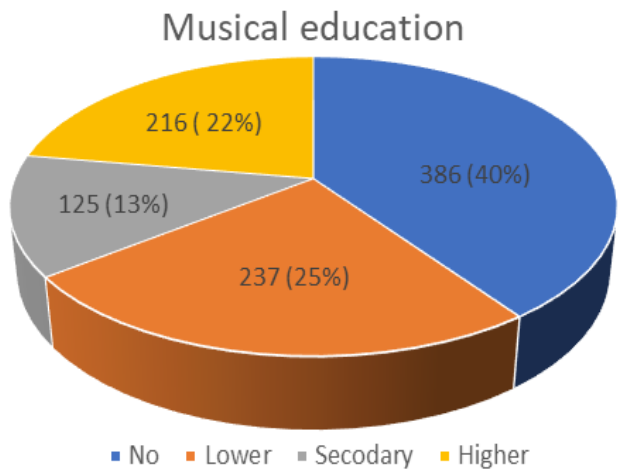

Fig. 1 Data analysis and discussion

In order to obtain the examinees' rates of sound, visual and complete experience of the first and second performances of the piece with exaggerated and deadpan gestures, a five-item rating scale with responses ranging from 1 (bad) to 5 (excellent) was offered. Figure 2 shows that the majority of the examinees rated sound experience of the first performer as very good $(\mathrm{N}=336,34.9 \%)$ or excellent $(\mathrm{N}=333,34.5 \%)$ while only 17 examinees $(1.8 \%)$ rated the sound experience of the first performer as bad.

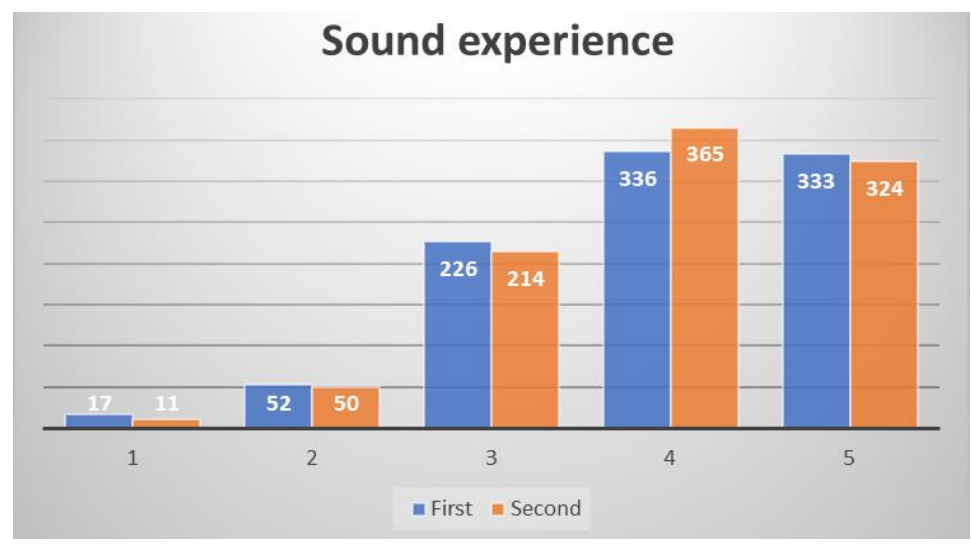

Fig. 2 Sound experience of the first and the second performers

Figure 2 shows that the majority of examinees rated the sound experience of the second performer as very good $(\mathrm{N}=365,37.9 \%)$ and excellent $(\mathrm{N}=324,33.6 \%)$. A smaller number of the interviewed $(\mathrm{N}=11,1.1 \%)$ rated the sound experience of this performer as bad. If we compare mean rates for sound experience of the first and the second performers, we can conclude that both are similar $\left(\mathrm{M}_{1}=3.95\right.$ and $\left.\mathrm{M}_{2}=3.98\right)$. Considering the rates for visual experience of the first and second performers we can find bigger 
differences in responses of examinees (Figure 3). A much greater number of examinees rated the visual aspect of the first performance with low rates - bad $(B=150,15.6 \%)$ and not very $\operatorname{good}(\mathrm{N}=180,18.7 \%)$ in comparison to the second performance where only 38 examinees $(3.9 \%)$ thought that visual experience was bad or not very good $(\mathrm{N}=110,11.4 \%)$.

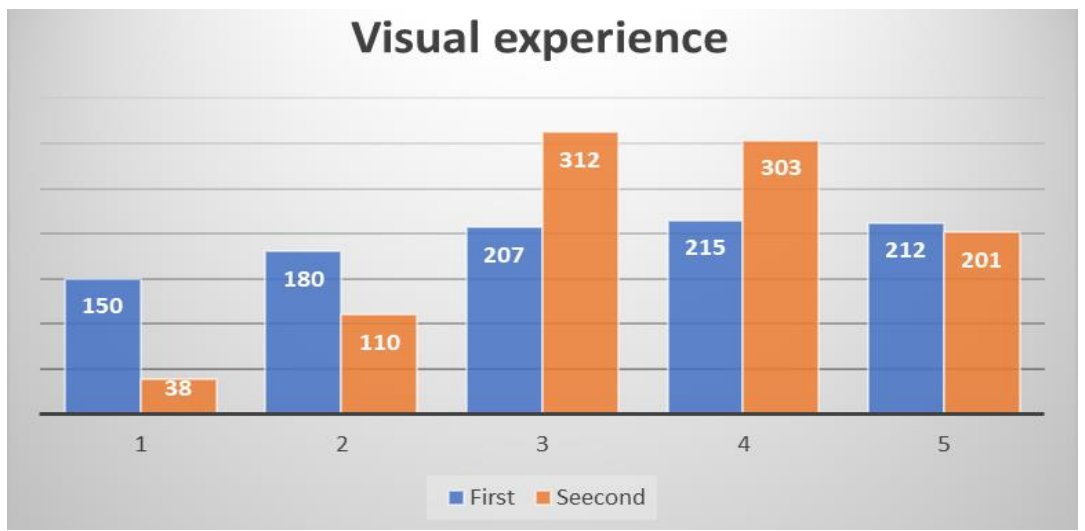

Fig. 3 Visual experience of the performers

Considering mean rates for visual experience, the examinees rated the visual experience of the second performer as better $\left(\mathrm{M}_{2}=3.54\right)$ in comparison to the first performer $\left(\mathrm{M}_{1}=3.16\right)$.

The next figure shows rating results for complete experience, i.e. overall musical experience while listening and watching the first and the second performances. Complete experience for the first performer was rated mostly as very good $(\mathrm{N}=319,33.1 \%)$, good $(\mathrm{N}=268,27.8 \%)$ or excellent $(\mathrm{N}=220,22.8 \%)$. The experience of complete performance of the second performer was mainly very good $(\mathrm{N}=396,41.1 \%)$, excellent $(\mathrm{N}=243$, $25.2 \%)$ or good $(\mathrm{N}=239,24.8 \%)$. Bad experience of complete performance of the first performer was rated by 28 examinees (3.9\%), while of the second by only $19(2.0 \%)$.

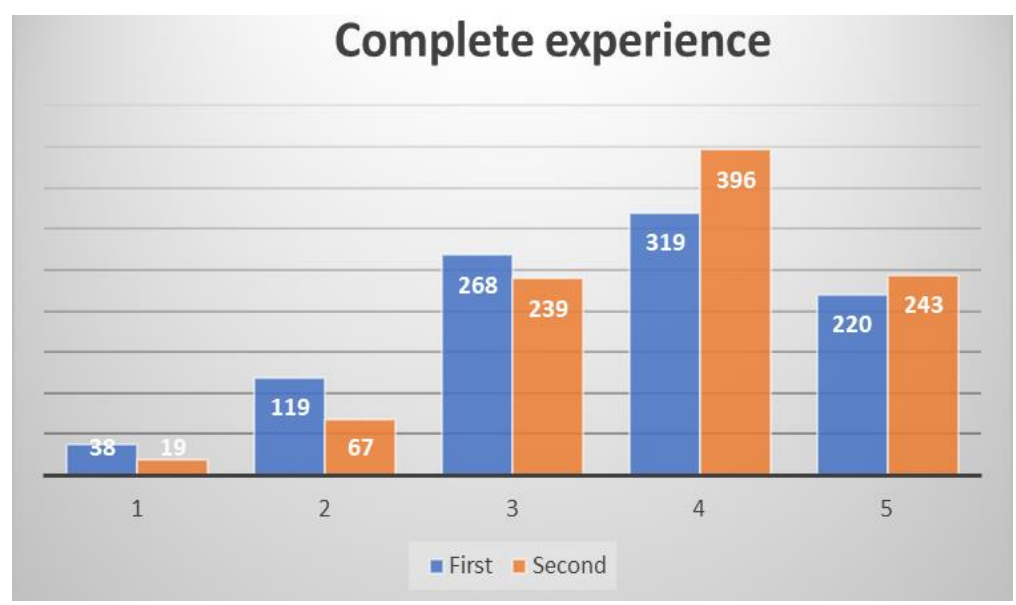

Fig. 4 Complete musical experience of performers 
In order to investigate whether there were any differences in the experience of examinees between those with and without formal musical education, the obtained results were checked by using $\mathrm{t}$-test for independent samples (Table 1 ).

Table 1 Results of t-test for comparison of experience of the examinees with and without musical education

\begin{tabular}{|c|c|c|c|c|c|c|}
\hline & Musical education & $\mathrm{N}$ & $\mathrm{M}$ & $\mathrm{SD}$ & $\mathrm{t}$ & $P$ \\
\hline \multirow{2}{*}{$\begin{array}{l}\text { Sound } \\
\text { experience } 1\end{array}$} & Yes & 578 & 4.05 & 0.92 & \multirow{2}{*}{3.920} & \multirow{2}{*}{.000} \\
\hline & No & 386 & 3.80 & 1.03 & & \\
\hline \multirow{2}{*}{$\begin{array}{l}\text { Sound } \\
\text { experience } 2\end{array}$} & Yes & 578 & 4.02 & 0.90 & \multirow{2}{*}{1.963} & \multirow{2}{*}{.050} \\
\hline & No & 386 & 3.90 & 0.98 & & \\
\hline \multirow{2}{*}{$\begin{array}{l}\text { Visual } \\
\text { experience } 1\end{array}$} & Yes & 578 & 3.02 & 1.38 & \multirow{2}{*}{-3.921} & \multirow{2}{*}{.000} \\
\hline & No & 386 & 3.38 & 1.33 & & \\
\hline \multirow{2}{*}{$\begin{array}{l}\text { Visual } \\
\text { experience } 2\end{array}$} & Yes & 578 & 3.61 & 1.03 & \multirow{2}{*}{2.529} & \multirow{2}{*}{.012} \\
\hline & No & 386 & 3.43 & 1.11 & & \\
\hline \multirow{2}{*}{$\begin{array}{l}\text { Complete } \\
\text { experience } 1\end{array}$} & Yes & 578 & 3.58 & 1.08 & \multirow{2}{*}{-.312} & \multirow{2}{*}{.755} \\
\hline & No & 386 & 3.60 & 1.10 & & \\
\hline \multirow{2}{*}{$\begin{array}{l}\text { Complete } \\
\text { experience } 2\end{array}$} & Yes & 578 & 3.86 & 0.93 & \multirow{2}{*}{2.069} & \multirow{2}{*}{.039} \\
\hline & No & 386 & 3.73 & 1.00 & & \\
\hline
\end{tabular}

The results of the test showed significant differences in rates of examinees with and without musical education related to rating of sound and visual experience for both performers, as well as for rating of the complete experience for the second performer. In comparison to other examinees, professional musicians rated more highly sound experience of the two performers, visual experience of the second performer and complete experience of the second performer. On the other hand, in comparison to musicians the examinees without musical training rated more highly visual experience of the first performer.

One of the questions related to "communication" i.e. relationship with the audience that was established by performers. Figure 5 shows that a greater number of examinees think that the first performer established better communication $(\mathrm{N}=577,60.4 \%)$, while $379(39.6 \%)$ examinees opted for the second performer.

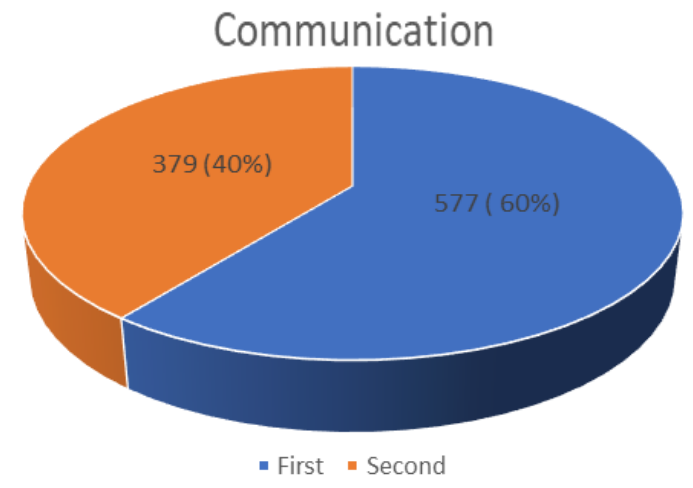

Fig. 5 Communication of performers 
Considering exaggerated gestures, characteristic for the first interpretation of the piece, the examinees expressed their opinion whether this model of visualisation was spontaneous. Figure 6 shows that greater number of examinees think the gestures were not spontaneous $(\mathrm{N}=553,57.6 \%)$, while 407 examinees $(42.4 \%)$ think the gestures were spontaneous.

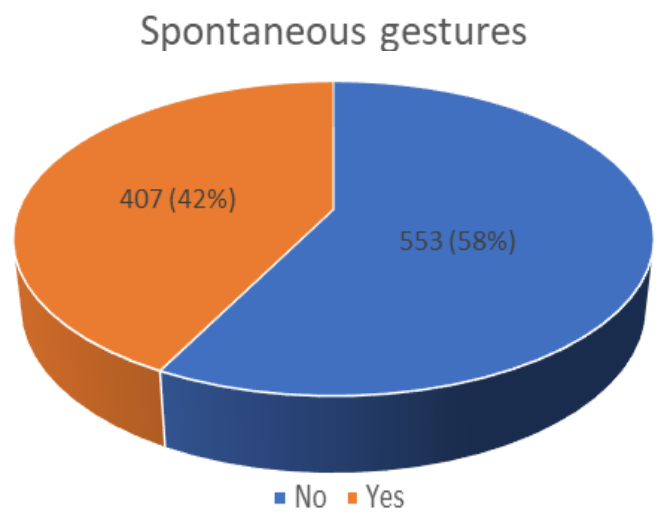

Fig. 6 Spontaneous gestures of the first performer

Figure 7 shows the distribution of answers related to the effect of gestures on complete experience. Most of the examinees $(620,64 \%)$ think that gestures affect the experience, 200 $(20.7 \%)$ have opposite opinion, while 144 examinees (14.9\%) do not have a clear attitude.

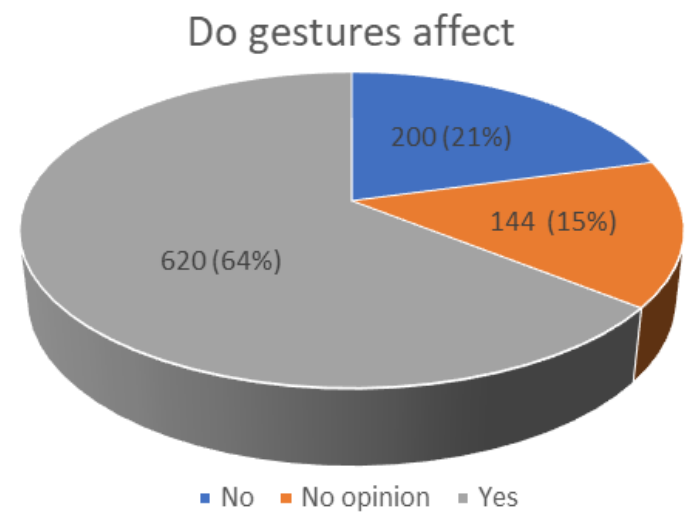

Fig. 7 Do gestures affect complete experience

Considering the last three questions in the questionnaire, we examined whether the answers related to communication with the audience, spontaneity of gestures in the first performance, and the attitude about the effect of gestures on complete experience of a musical piece differed between the examinees with and without musical education. These differences were investigated by using the Chi-Square test (Table 2). 
Table 2 The results of the Chi-Square test in investigating the differences in experience between the examinees with and without musical education.

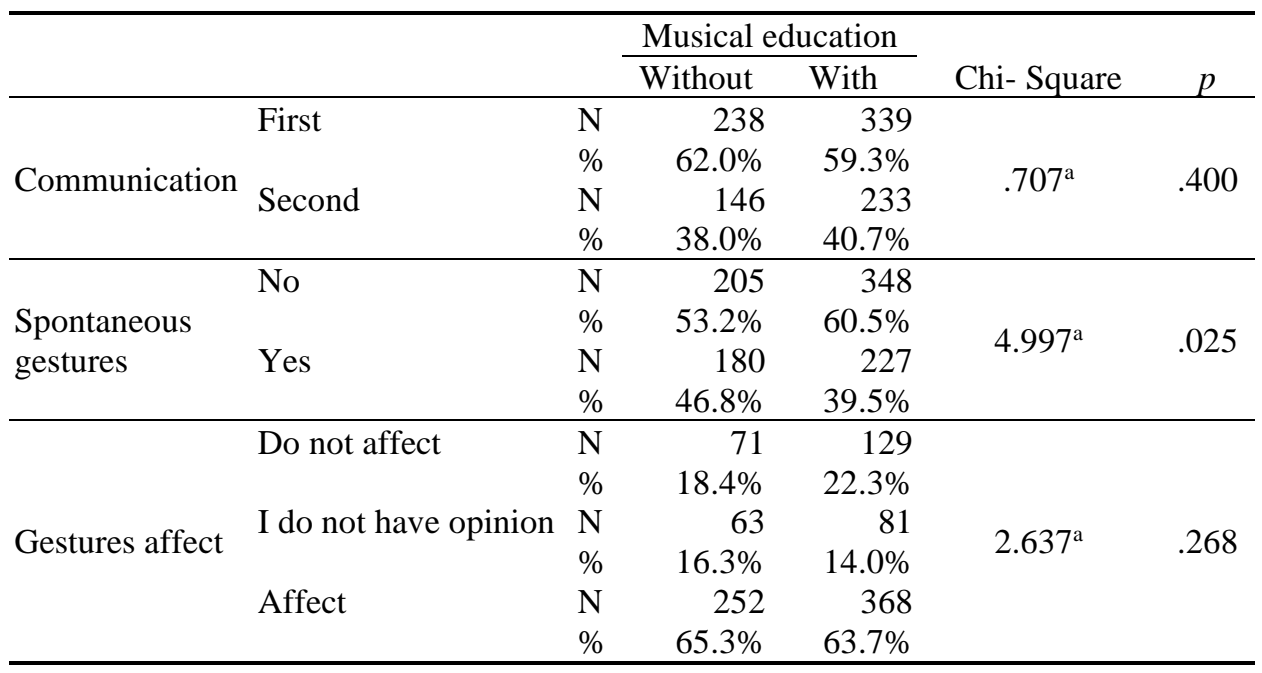

According to the results of the test, significant differences can be found only in answers related to the spontaneous gestures of the first performer. Although the majority of the examinees, both with and without musical education think that gestures of the first performer are not spontaneous, the percentage is significantly higher $(60.5 \%)$ in the examinees with musical education in comparison to the examinees without musical education $(53.2 \%)$. If we consider the subgroup of examinees with higher musical education only, we will notice even bigger differences, since $68.1 \%$ of them (147) think that the gestures during the first performance were not spontaneous. Answers to the other two questions for examinees with and without musical education were consistent. This can be seen in Figures 8 and 9.

\section{Communication}

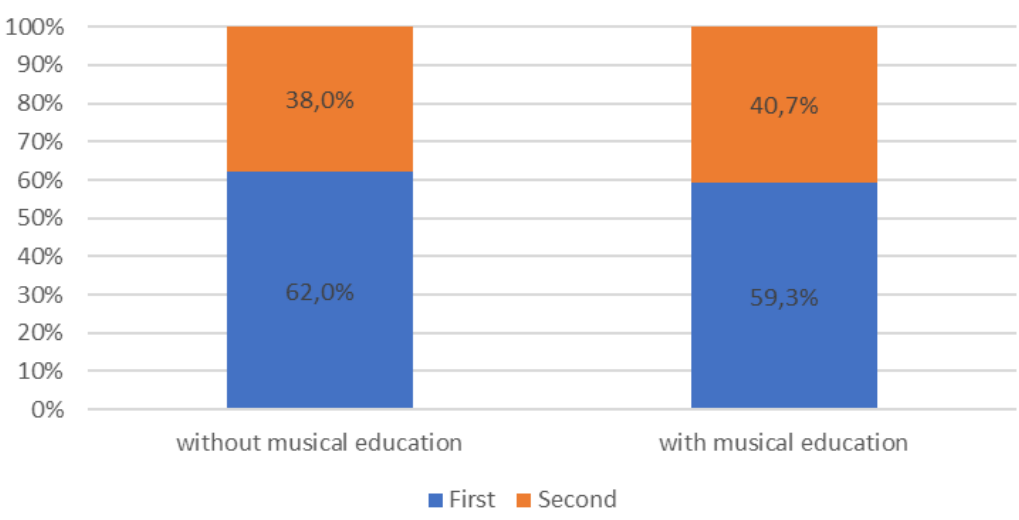

Fig. 8 Communication of performers 


\section{Do gestures affect experience}

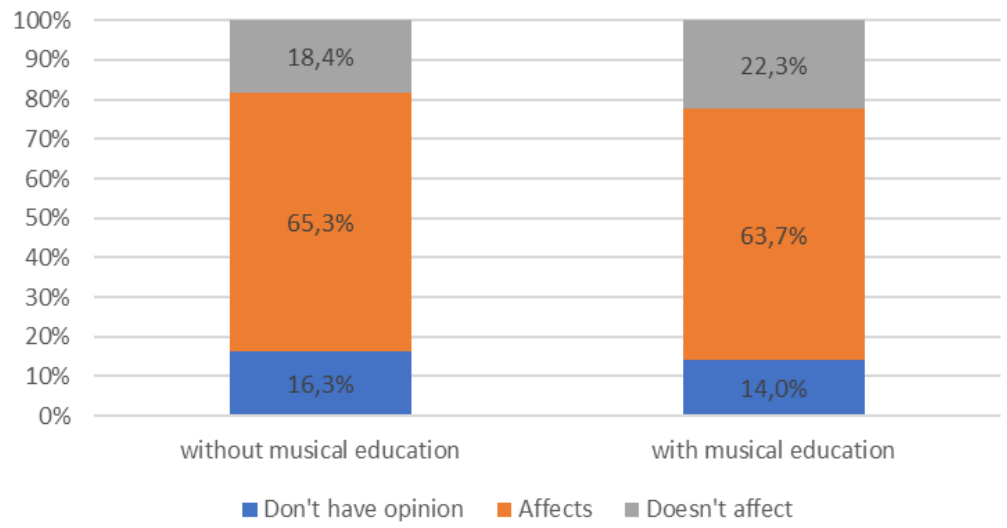

Fig. 9 Do gestures affect complete experience

\section{CONCLUSION}

In our paper we concluded that musical gestures were far from being negligible as part of musical performance; rather, they were very significant for the complete experience of a musical piece. We presented studies where numerous researchers of musical gestures reported their findings, and what they came to know. We stated that a study of this area of psychology could be conducted by using various research methods, that various aspects could affect specific gestures as well as reasons why performers made them during their performance.

In our research numerous answers were obtained by listeners related to perception of exaggerated and deadpan gestures. According to the analysis of responses, the examinees rated sound experience of both performers mainly as very good or excellent, hence we found approximately equal rates of sound experience $\left(\mathrm{M}_{1}=3.95\right.$ and $\left.\mathrm{M}_{2}=3.98\right)$. Somewhat greater differences could be found in the rates of visual experience, since the visual experience of the second performer was rated as better $\left(\mathrm{M}_{2}=3.54\right)$ in comparison to the first performer $\left(\mathrm{M}_{1}=3.16\right)$. In further data processing, complete experience was rated, i.e. musical impression while listening and watching the interpretation of the piece by both first and second performers. The results of answers for the first performer were as following: very good $(\mathrm{N}=319,33.1 \%)$, good $(\mathrm{N}=268,27.8 \%)$ and excellent $(\mathrm{N}=220$, $22.8 \%)$, while for the second performer they were very good ( $\mathrm{N}=396,41.1 \%)$, excellent $(\mathrm{N}=243,25.2 \%)$ and $\operatorname{good}(\mathrm{N}=239,24.8 \%)$.

One of the parameters in our research considered identification of differences in the answers of examinees with formal musical education in comparison to those without it. Educated musicians rated more highly the domains of sound experience of the two performers, visual experience of the second performer and complete experience transmitted by the second performer, while the examinees without musical training assessed with significantly higher rates the visual experience of the first performer.

A significant parameter in responses of the examinees was related to the "communication" that performers established during their performance. According to the results of research, the 
first performer with exaggerated gestures was obviously more successful in "communication" $(60.4 \%)$, in comparison to the second performer who hardly had any gestures during his performance $(39.6 \%)$. According to the answers of examinees, the majority of them thought that gestures were not spontaneous $(57.6 \%)$ in comparison to those who thought that gestures were spontaneous $(42.4 \%)$. While analysing the answers to the question whether expressive gestures significantly affected complete experience of a musical piece, we could conclude that the majority of examinees $(64.3 \%)$ agreed to this statement, $20.7 \%$ had opposite attitude, while $14.9 \%$ did not have a clear attitude.

By analysing the data related to communication of the performers with the audience, spontaneity of gestures in the first performance and the attitude whether gestures affected complete experience of a musical piece we wanted to identify the difference between answers of examinees with and without musical education. The answers obtained from these two categories of examinees were statistically consistent, except those related to the issue of spontaneous gestures of the first performer. Concerning the statement that the gestures of the first performer were not spontaneous, there was statistical significance in the answers of the examinees with musical education $(60.5 \%)$ in relation to those without musical education $(53.2 \%)$. Moreover, $68.1 \%$ of the examinees with higher musical education thought that the gestures of the first performer were not spontaneous.

Bearing in mind the fact that in this study, besides gestures, other parameters that appear in the video (younger person in the foreground, older person in the background, better quality of video etc.) can also affect perception of listeners/viewers, we can draw the following conclusions:

a) According to the opinion of the audience, deadpan gestures are more appropriate in comparison to exaggerated gestures during a performance.

b) The audience with formal musical education have worse experience of exaggerated gestures in comparison to the audience without musical education.

c) The use of gestures during performance improves communication with the audience. However, exaggerated gestures disturb visual (and also aural in the audience without musical education) experience during performance, which confirms the initial hypothesis of Davidson (2002).

g) During performance, the audience cannot recognise the spontaneity of gestures.

Further research is necessary in order to clarify the effect of using various gestures during performance. The findings of such research could be compared to the results of this study; thus it could be possible to scientifically identify which gestures the audience would consider most appropriate during the performance.

\section{REFERENCES}

Ačić, G., Nedeljković, M., Petrović, V., Milanković, V., Galikowska Gajewska, A., Konkol, G. K., Kierzkowski, M., (2019), "The Influence of Eurhythmics Method (Selected Tasks and Exercises of Dalcroze's Method) on Motor Skills and a Sense of Pulse”, In: Petrović, M. (ed.) Theoretical and artistic in the pedagogy of performing arts, proceding of the 21th Pedagogical Forum of Performing Arts, Belgrade: pp. $15-24$.

Davidson, J. W., (1994) "Which areas of a pianist's body convey information about expressive intention to an audience?", Journal of Human Movement Studies, Vol. 26: pp. 279-301.

Davidson, J., (1993), "Visual perception of performance manner in the movements of solo musicians", Psychology of Music, 2, Vol. 21: pp. 103-113. 
Davidson, J. and Correia, J.S., (2002), Body movement, In: Parncutt, R. \& McPherson, G.E. (eds.) The science and psychology of music performance: Creative strategies for teaching and learning, Oxford, Oxford University Press: pp. 237-250.

Delalande, F., (1988), "La gestique de Gould”, In: Courteau, L. (ed.) Glenn Gould Pluriel, Que bec: pp. 85-111.

Ekman, P. and Friesen, W. V., (1969), "The repertoire of nonverbal behavior: categories, origins, usage, and coding", Semiotics, 1, Vol. 1: pp. 49-98.

Gellrich, M., (1991), "Concentration and tension”, British Journal of Music Education, 2, Vol. 8: pp. 167-179.

Johansson, G., (1973), "Visual perception of biological motion and a model for its analysis", Perception \& Psychophysics, 2, Vol. 14: pp. 201-211.

Kršić Sekulić, V., (1990), Korelacija nastave solfeđa sa instrumentalnom nastavom, Nolit, Beograd.

Laberge, C.M., Cossette, I., Wanderley, M., (2016), "Hearing the Gesture: Perception of Body Actions in Romantic Piano Performances", In: Proceedings of the International Conference for Music Perception and Cognition, San Francisco: pp. 1-5.

Livingstone, S., Palmer, C., Wanderley, M., Thompson, W.F. and Lissemore, J., (2011), "Facial expressions in vocal performance: Visual communication of emotion”, In: Williamon, A., Edwards, D. and Bartel, L. (eds.), Proceedings of the International Symposium on Performance Science 2011, European Association of Conservatoires, Utrecht: pp. 545-550.

McNeill, D. (1992), Hand and Mind: what gestures reveal about thought, University of Chicago Press, Chicago.

McNeill, D., Quek, F., McCullough, K.E., Duncan, S., Bryll, R., Ma, X.F., and Ansari, R., (2002), "Dynamic imagery in speech and gesture”, In: Granström, B., House, D. \& Karlsson, I. (eds.), Multimodality in language and speech systems, Vol. 19, Kluwer Academic Publishers, Dordrecht: pp. 27-44.

Newlin, D., (1980), Schoenberg Remembered: Diaries and Recollections (1938-76). Pendragon Press, New York. Thompson, R., (2007), Expressive Gestures in Piano Performance, Master's Thesis, University of Jyväskylä.

Todorović, D., (2006), "Fraziranje - poetika izvođačkog pokreta", Zbornik sedmog pedagoškog foruma, Fakultet muzičke umetnosti, Beograd: pp. 74-81.

\section{UTICAJ MUZIČKIH GESTIKULACIJA NA PUBLIKU: PRETERANE I NEIZRAŽAJNE GESTIKULACIJE}

Sa razvojem tehnologije za prikupljanje podataka u poslednje dve decenije izrazito se povećao broj naučnih radova čije je područje istraživanja povezano sa proučavanjem muzičkih gestikulacija. Cilj ovog rada je da to aktuelno područje muzičke psihologije dopuni istraživanjem muzičkih gestikulacija tokom izvođenja, odnosno da protumači i sistematizuje vizuelene doživljaje publike kada izvođač primenjuje preterane ili neizražajne gestikulacije tokom nastupa. Ova studija temelji se na metodi anketnog istraživanja gde su ispitanici na skali od 1 do 5 ocenili izvođenja dvojce pijanista. Prvi izvođač je tokom nastupa imao preterane gestikulacije, dok je drugi imao neizrazite. Rezultati su pokazali da preterana gestikulacija remeti vizuelni doživljaj slušalaca prilikom izvođenja, bez obzira na to da li on poseduje formalno muzičko obrazovanje ili ne. Dobijeni nalazi predstavljaju važan doprinos proučavanju gestikulacije u muzici i mogu naći svoju primernu kako u oblasti pedagogije tako i u oblasti muzičkog izvođaštva.

Ključne reči: gestikulacija, pokret, izražaj, klavirski nastup, percepcija 